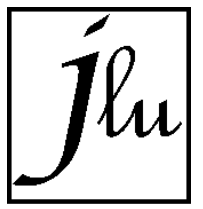

Jurnal Luminous:

E-ISSN 2715-6990

Riset IImiah Pendidikan Fisika

P-ISSN 2715-9582

Vol. 1 No. 2 (2020) hal 53-64

Juli 2020

https://jurnal.univpgri-

palembang.ac.id/index.

php/luminous

\title{
PENGARUH PENDEKATAN CONTEXTUAL TEACHING AND LEARNING (CTL) MENGGUNAKAN LABORATORIUM TERHADAP KEMAMPUAN PEMECAHAN MASALAH SISWA DI SMP NEGERI 1 RAMBANG
}

\author{
Marnia Ade Putri ${ }^{1}$, Prof. Fuad Abd Rachman ${ }^{2}$, Sugiarti, M.Pd ${ }^{3}$ \\ ${ }^{1}$ (Program Studi Pendidikan Fisika, FKIP, Universitas PGRI Palembang) \\ Palembang, Indonesia \\ marniaadeputri26@gmail.com \\ ${ }^{2}$ (Program Studi Pendidikan Kimia, FKIP, Universitas Sriwijaya) \\ Palembang, Indonesia \\ fuad.abdrachman@yahoo.co.id \\ ${ }^{3}$ (Program Studi Pendidikan Fisika, FKIP, Universitas PGRI Palembang) \\ Palembang, Indonesia \\ sugiartialatiq@gmail.com
}

Received: 28 April 2020. Accepted: 25 Juni 2020. Published: Juli 2020

\section{Abstrak}

Pendekatan contextual teaching and learning (CTL) adalah pendekatan pembelajaran yang mengaitkan materi pelajaran dengan kehidupan nyata, dipadukan dengan kegiatan laboratorium yang menghubungkan antara teori/konsep dan praktek sehingga membuat pemahaman mendalam dan bermakna. Pengumpulan data dilaksanakan pada tanggal 6 Agustus 2018 sampai dengan tanggal 14 Agustus 2018 di SMP Negeri 1 Rambang tahun pelajaran 2018/2019. Penelitian ini bertujuan untuk mengetahui pengaruh pendekatan contextual teaching and learning (CTL) menggunakan laboratorium terhadap kemampuan pemecahan masalah siswa di SMP Negeri 1 Rambang. Metode penelitian yang digunakan dalam penelitian ini adalah quasi eksperimental dengan desain pretest-posttest control group design. Populasi dalam penelitian ini adalah seluruh siswa kelas VIII SMP Negeri 1 Rambang yang terdiri dari 4 kelas dan berjumlah 108 orang. Pengambilan sampel dilakukan dengan teknik sampling klaster (sampel berkelompok) dan mengambil 2 kelas dari 4 kelas dari populasi. Teknik pengumpulan data menggunakan tes. Berdasarkan hasil penelitian dan analisis data dengan pengujian hipotesis menggunakan uji statistik uji-t (uji pihak kanan), dari perhitungan tersebut didapat $t_{\text {hitung }}>t_{\text {tabel }}$, yaitu 2,51 $>1,67$ maka $\mathrm{H}_{0}$ ditolak dan $\mathrm{H}_{\mathrm{a}}$ diterima, dengan demikian dapat disimpulkan bahwa ada pengaruh pendekatan contextual teaching and learning (CTL) menggunakan laboratorium terhadap kemampuan pemecahan masalah siswa di SMP Negeri 1 Rambang tahun pelajaran 2018/2019.

\section{(C) 2018 Pendidikan Fisika FKIP UPGRI Palembang}

Kata Kunci: Pendekatan Contextual Teaching and Learning (CTL), Laboratorium, Kemampuan Pemecahan Masalah

\section{PENDAHULUAN}

Pendidikan sangat penting bagi dalam kehidupan manusia. Manusia yang berpendidikan kehidupannya akan selalu berkembang ke arah yang lebih baik. Untuk itu maka dibutuhkan suatu pembelajaran yang dapat mengembangkan berbagai kompetensi siswa. IImu yang dapat mengembangkan berbagai kompetensi siswa yang harus dipelajari dalam materi pelajaran disekolah adalah IImu Pengetahuan Alam (IPA). 
IImu pengetahuan alam (IPA) adalah mata pelajaran yang mempelajari fenomena alam melalui kegiatan penyelidikan yang disusun secara sistematis dan merupakan salah satu mata pelajaran yang sangat penting dan selalu diberikan pada setiap jenjang pendidikan. salah satu bagian dari IPA adalah fisika. Fisika merupakan bagian dari pembelajaran modern yang tidak hanya menuntut siswa menguasai konsep namun juga mengembangkan berbagai kompetensi siswa yaitu keterampilan berpikir.

Salah satu keterampilan berpikir yang dapat dikembangkan menurut Marzano (dalam Hafizah et al, 2014, hal. 8) adalah kemampuan pemecahan masalah. Sejalan dengan tujuan mata pelajaran fisika salah satunya adalah mengembangkan kemampuan pemecahan masalah dalam berfikir analisis, deduktif dan induktif dengan menggunakan prinsip fisika untuk menjelaskan serta menyelesaikan masalah baik kualitatif maupun kuantitatif.

Kemampuan pemecahan masalah berguna untuk melahirkan solusi inovatif dalam menghadapi permasalahan-permasalahan dunia saat ini dan yang akan datang, sehingga kemampuan pemecahan masalah menjadi salah satu standar kompetensi dasar yang harus dicapai siswa pada abad 21 (Prihartanti et al, 2017, hal. 1149). Kemampuan pemecahan masalah merupakan kemampuan kognitif tingkat tinggi, tahap berfikir pemecahan masalah setelah tahap evaluasi yang menjadi bagian dari tahapan kognitif Bloom. Untuk menyelesaikan masalah, siswa memerlukan suatu keterampilan dan kemampuan khusus yang harus dimiliki, yang mungkin akan berbeda antar siswa dalam menyelesaikan suatu masalah.

Pemecahan masalah merupakan bagian dari kurikulum fisika yang sangat penting karena dalam proses pembelajaran maupun penyelesaiannya, siswa dimungkinkan memperoleh pengalaman menggunakan pengetahuan serta keterampilan yang sudah dimiliki untuk diterapkan pada pemecahan masalah menurut Sukmadinata dan As'ari (dalam Venisari et al. 2015. 194). Pemecahan masalah adalah suatu proses menerima masalah dan mencari jalan keluar untuk mencapai tujuan (Taqiyyah et al, 2017, hal. 226 ). Kemampuan pemecahan masalah merupakan kemampuan tingkat tinggi, tahap berfikir pemecahan masalah setelah tahap evaluasi yang menjadi bagian dari tahapan kognitif Bloom (Venisari et al, 2015, hal. 194). Berdasarkan beberapa pendapat tersebut peneliti menyimpulkan bahwa kemampuan pemecahan masalah adalah suatu proses menentukan solusi untuk suatu masalah yang di hadapi. Adapun indikator kemampuan pemecahan masalah yaitu: 1. memahami masalah, 2. merencanakan penyelesaian masalah, 3 . menyelesaikan masalah, dan 4. memeriksa kembali jawaban. Kemampuan pemecahan masalah yang dimaksud dalam penelitian ini adalah kemampuan siswa menggunakan pengetahuan dan konsep yang dipelajarinya untuk menyelesaikan soal-soal yang mengacu pada empat indikator kemampuan pemecahan masalah tersebut.

Dalam aktivitas pemecahan masalah siswa cenderung langsung mencari jawaban dan tidak mengetahui proses dalam menyelesaikan 
persoalan masalah tersebut. Menurut Mazur (dalam Prihartanti et al, 20117, hal. 1150) banyak siswa yang berhasil menyelesaikan soal fisika dengan menerapkan rumus fisika dalam prosedur matematis tanpa mengetahui konsep di belakangnya. Proses berfikir dalam pemecahan masalah merupakan hal penting yang perlu untuk membantu siswa agar dapat mengembangkan kemampuannya memecahkan masalah. Keuntungan yang diperoleh ketika memecahkan masalah dilakukan dengan melibatkan kemampuan terhadap proses berfikir serta kemampuan mengontrol diri, sehingga dapat membangun pemahaman yang kuat dan menyelesaikan masalah dengan alasan yang logis (Anggo, dalam Taqiyyah et al, 2017, hal. 226)

Berdasarkan observasi dan wawancara yang didapatkan peneliti dari guru bidang studi IImu Pengetahuan Alam kelas VIII di SMP Negeri 1 Rambang sudah menerapkan kurikulum terbaru yaitu kurikulum 2013, kriteria ketuntasan minimum (KKM) yaitu 72 dan. Guru bidang studi sudah menggunakan beberapa metode-metode dalam proses pembelajaran, seperti tanya jawab dan diskusi, namun nilai tes hasil belajar siswa masih banyak yang mendapatkan nilai di bawah KKM. Hal ini dikarenakan kemampuan pemecahan masalah siswa rendah, yang terlihat dari banyaknya siswa kesulitan menyelesaikan soal ujian yang guru berikan. Karena pada saat siswa di beri soal latihan, siswa cenderung menyalin tugas tanpa mau berpikir saat menyelesaikan soal. Sejalan dengan pendapat Venisari et al (2015, hal. 194) yang menyatakan bahwa kemampuan pemecahan masalah siswa rendah ditunjukkan dari hasil ujian siswa yang masih rendah.
Peneliti juga mendapatkan informasi bahwa kegiatan pembelajaran IPA khususnya fisika lebih dominan pelajaran dilaksanakan di dalam kelas. Pembelajaran yang selama ini mereka terima hanyalah penonjolan tingkat hafalan dari sekian pokok bahasan. Sehingga mengakibatkan pengetahuan yang dimiliki siswa hanya sebatas yang diberikan guru dan membuat siswa hanya mengingat untuk waktu yang singkat, tanpa memahami apa yang dipelajari. Hal ini mengakibatkan siswa kesulitan untuk menyelesaikan persoalan-persoalan yang ada. Mereka akan lebih mudah menyelesaikan persoalan-persoalan yang dihadapi jika membangun sendiri pengetahuan dan dengan pengalaman nyata.

Salah satu materi fisika yang memerlukan keterampilan pemecahan masalah adalah materi gaya dan hukum Newton. Banyak peneliti yang mengungkapkan bahwa dalam memecahkan masalah, peserta didik mengalami misunderstanding dan miskonsepsi tentang hukum Newton (Nurcahyo et al, 2017, hal. 963). Sebagai cabang ilmu fisika yang sangat penting dan mendasar, penguasaan materi gaya dan hukum Newton adalah modal utama untuk mempelajari cabang ilmu fisika lainnya (Sutopo, dalam Nurcahyo et al, 2017, hal 963).

Berdasarkan masalah diatas, maka untuk meningkatkan kemampuan pemecahan masalah siswa dibutuhkan pembelajaran konstruktivis (Prihartanti et al, 2017, hal. 1150). Pembelajaran konstruktivis merupakan pembelajaran dimana siswa membangun sendiri pengetahuannya. Salah satu pendekatan pembelajaran yang menganut paham konstruktivisme adalah pendekatan 
pembelajaran contextual teaching and learning (CTL). Hal ini sejalan dengan penelitian Cochran et al (dalam Sari et al, 2014, hal. 58) yang menyatakan bahwa keuntungan pembelajaran dengan pendekatan CTL bagi siswa dapat memperdalam pemahaman dan pemecahan masalah.

\section{Contextual teaching and learning (CTL)} disebut pendekatan kontekstual karena konsep belajar yang membantu guru mengaitkan antara materi yang diajarkanyan dengan situasi dunia nyata siswa dan mendorong siswa membuat hubungan antara pengetahuan yang dimilikinya dengan penerapannya dalam kehidupan mereka sebagai anggota keluarga dan masyarakat (Sari et al, 2017, hal. 23). Menurut Ernayeti (2018, hal. 130) Pendekatan CTL merupakan pembelajaran yang menghubungkan antara meteri yang diajarkan dengan situasi dunia nyata siswa yang bertujuan membekali siswa dengan pengetahuan yang secara fleksibel dapat diterapkan atau ditransfer dari suatu permasalahan yang satu kepermasalahan yang lain dan dari konteks satu ke konteks yang lain. Sanjaya (2011, hal. 109) adalah suatu pendekatan pembelajaran yang menekankan kepada proses keterlibatan siswa secara penuh untuk dapat menemukan materi yang dipelajari dan menghubungkannya dengan situasi kehidupan nyata sehingga mendorong siswa untuk dapat menerapkannya dalam kehidupan mereka.

Dapat disimpulkan bahwa pendekatan CTL merupakan pedoman pembelajaran yang mengaitkan setiap materi atau topik pembelajaran dengan kehidupan nyata sehingga siswa dapat menangkap pengetahuan dari kenyataan dan membuat hubungan untuk memecahkan permasalahan. Dalam proses belajar dengan pembelajaran contextual teaching and learning (CTL) terdapat langkah-langkah (Sabroni, 2017) sebagai berikut:

1. Mengembangkan pemikiran bahwa anak akan belajar lebih bermakna dengan cara bekerja dengan menciptakan masyarakat belajar.

2. Melakukan kegiatan penemuan dalam semua pembelajaran.

3. Mengembangkan sifat ingin tahu peserta didik dengan bertanya.

4. Menghadirkan model atau media sebagai contoh belajar peserta didik.

5. Melakukan refleksi di akhir petemuan.

6. Melakukan penilaian atas hasil yang di capai peserta didik.

Sebuah kelas dikatakan menggunakan pendekatan CTL jika menerapkan ketujuh komponen pembelajaran CTL (Trianto, dalam Antika et al, 2016, hal. 231), yaitu: 1 . Konstruktivisme, adalah proses membangun atau menyusun pengetahuan baru dalam struktur kognitif siswa berdasarkan pengalaman., 2. inkuiri artinya proses pembelajaran didasarkan pada pencarian dan penemuan melalui proses berpikir secara sistematis, 3. bertanya (questioning) dapat dipadang sebagai refleksi dari keingintahuan setiap individu sedangkan menjawab pertanyaan mencerminkan kemampuan seseorang dalam berfikir, 4. masyarakat belajar (learning community) Belajar merupakan sharing dengan teman atau kerjasama dengan orang lain dan saling memberi informasi, 5 . pemodelan (modeling) adalah proses pembelajaran dengan memperagakan sesuatu sebagai contoh yang 
dapat ditiru oleh setiap siswa, 6. refleksi (reflection) adalah proses pengendapan pengalaman yang telah dipelajari yang dilakukan dengan cara mengurutkan kembali kejadiankejadian atau peristiwa pembelajaran yang telah dilaluiya dan 7 . penilaian nyata (authentic assessment) adalah proses yang dilakukan guru untuk mengumpulkan informasi tentang perkembangan belajar yang dilakukan siswa.

kelebihan pendekatan contextual teaching and learning (CTL) yaitu: 1) pembelajaran akan lebih bermakna dan rill, karena siswa dituntut untuk dapat menangkap hubungan antara pengalaman belajar di sekolah dengan kehidupan nyata sehingga konsep yang dipelajari akan tertanam erat di memori siswa, 2) menumbuhkan keberanian siswa untuk mengemukakan pendapat, 3) menumbuhkan rasa ingin tahu siswa, dan 4) menumbuhkan kemampuan dalam bekerjasama dengan teman yang lain untuk memecahkan masalah yang ada. Sedangkan kelemahan dalam pembelajaran CTL yaitu: 1) guru lebih intensif dalam membimbing karena dalam pembelajaran CTL guru tidak lagi berperan sebagai pusat informasi dan memerlukan waktu yang lama dalam pembelajaran, 2) bagi siswa yang tidak dapat mengikuti pelajaran, tidak mendapatkan pengetahuan dan pengalaman yang sama dengan teman lainnya karena siswa tidak mengalaminya sendiri.

Pendekatan contextual teaching and learning (CTL) hendaknya dipadukan dengan kegiatan yang dapat memperkuat pemahaman siswa serta dapat membuat pengalaman belajar siswa lebih bermakna untuk dapat mempermudah siswa menyelesaikan permasalahan. Oleh karena itu peneliti memadukan pendekatan CTL dengan menggunakan kegiatan laboratorium. Karena pembelajaran berbasis laboratorium sangat menunjang pembelajaran dengan pendekatan CTL (Adiaty et al, 2014, hal. 82). Laboratorium adalah suatu tempat dimana percobaan dan penyelidikan dilakukan (Limbong (2014, hal. 51). Menurut Decaprio dalam Rohmatin dan Budingarti (2017, hal. 210) kegiatan laboratorium membuat siswa akan lebih mempercayai kebenaran suatu teori berdasarkan percobaan, mampu menafsirkan hasil percobaan, dan terampil dalam menggunakan alat-alat percobaan. Alat-alat percobaan merupakan benda yang dapat membantu siswa praktikum. Peralatan praktikum bukan hanya peralatan yang terdapat di laboratorium saja, akan tetapi dapat juga menggunakan benda yang ada disekitar yang bisa dimanfaatkan untuk melakukan percobaan atau penyelidikan teori atau konsep.

Pembelajaran contextual teaching and learning ( $\mathrm{CTL}$ ) menggunakan laboratorium berarti pembelajaran konsep yang dilakukan bersamaan dengan kegiatan praktikum dengan membawa benda-benda yang ada disekitar ke laboratorium yang bertujuan agar siswa mendapatkan pengetahuan dari objek yang sesungguhnya sehingga apa yang telah dipelajari akan bertahan lama dalam ingatannya. Serta diharapkan dapat membantu siswa untuk menemukan sendiri pengetahuan dari pengalaman untuk diterapkan dalam kehidupan sehari-hari. Tujuan penelitian ini adalah untuk mengetahui ada tidaknya pengaruh pendekatan contextual taching and learning (CTL) menggunakan laboratorium terhadap kmampuan 
pemecahan masalah siswa di SMP Negeri 1 Rambang.

\section{METODE}

Penelitian ini adalah quasi experimental adapun desain yang digunakan penelitian ini adalah pretest-posttest control group design. Bentuk bagan desain tersebut adalah sebagai berikut (Sugiyono, 2015, hal. 112):

\begin{tabular}{|llll|}
\hline $\mathrm{R}$ & $\mathrm{O}_{1}$ & $\mathrm{X}$ & $\mathrm{O}_{2}$ \\
$\mathrm{R}$ & $\mathrm{O}_{3}$ & $\mathrm{C}$ & $\mathrm{O}_{4}$ \\
\hline
\end{tabular}

Gambar 1. Pretest-Posttest Control Group Design Keterangan :

$\mathrm{R}$ : Kelompok kelas eksperimen/ kontrol yang dipilih secara random

X: Perlakuan kelas yang menggunakan pendekatan contextual teaching and learning (CTL) menggunakan laboratorium.

C : Perlakuan kelas yang menggunakan pendekatan diskusi.

$\mathrm{O}_{1}$ : Tes awal sebelum diberikan perlakuan pendekatan contextual teaching and learning (CTL) menggunakan laboratorium.

$\mathrm{O}_{2}$ : Tes akhir setelah diberikan perlakuan pendekatan contextual teaching and learning (CTL) menggunakan laboratorium.

$\mathrm{O}_{3}$ : Tes awal sebelum diberikan perlakuan menggunakan metode diskusi.

$\mathrm{O}_{4}$ : Tes akhir setelah diberikan perlakuan menggunakan metode diskusi.

Penelitian ini dilaksanakan pada tanggal 6-

14 Agustus 2018 semester ganjil tahun ajaran 2018/2019. Populasi penelitian ini adalah siswa kelas VIII SMP Negeri 1 Rambang yang terdiri dari 4 kelas. Pengambilan sampel dengan menggunakan teknik sampling klaster pengambilan sampel dilakukan melalui dua tahap. Pertama peneliti mengundi semua kelas dari populasi yaitu empat setelah itu pada tahap kedua peneliti mengundi kembali dari kedua kelas tersebut untuk menentukan satu kelas eksperimen yang belajar menggunakan pendekatan contextual teaching and learning (CTL) menggunakan laboratorium yaitu kelas VIII.3 sedangkan kelas VIII.4 sebagai kelas kontrol.

Teknik pengumpulan data dengan menggunakan tes. Instrumen penelitian terlebih dahulu dilakukan validitas pada dosen validator, kemuduan dilakukan uji validitas, reliabilitas, tingkat kesurkaran dan daya pembeda sebelum dilakukan pengujian kepada siswa. Data penelitian yang diperoleh harus memenuhi uji prasyarat sebelum dilakukan uji hipotesis yaitu uji normalitas dengan menggunakan rumus chi kuadrat dan uji homogenitas dengan menggunakan uji $F$. Uji hipotesis dilakukan dengan menggunakan uji $t$ pihak kanan pada taraf signifikasi $5 \%$ dengan kriteria pengujian adalah tolak Ho jika $t_{\text {hitung }} \geq t_{\text {tabel }}$ dan terima Ho jika $t_{\text {hitung }}<t_{\text {tabel }}$.

\section{HASIL DAN PEMBAHASAN}

Tes yang digunakan dalam penelitian ini adalah tes kemampuan pemecahan masalah dengan jenis uraian (essay) sebanyak 5 soal yang mengacu pada indikator kemampuan pemecahan masalah yaitu memahami masalah, merencanakan penyelesaian masalah, menyelesaikan masalah, dan memeriksa kembali jawaban. Tes yang diberikan sebelum memulai kegiatan pembelajaran disebut pretest, sedangkan 
setelah kegiatan pembelajaran disebut posttest. Tes ini diberikan untuk melihat sejauh mana keterampilan pemecahan masalah siswa terhadap materi yang diajarkan dengan menggunakan pendekatan CTL menggunakan laboratorium.

Data tes dianalisis untuk mengetahui nilai yang diperoleh oleh siswa kelas VIII.3 (kelas eksperimen) maupun kelas VIII.4 (kelas kontrol). Tes diberikan dalam bentuk pretest dan posttest pada kedua kelas yaitu kelas eksperimen dan kelas kontrol. Tes diberikan untuk mengetahui pengaruh pendekatan contextual teaching and learning (CTL) menggunakan laboratorium terhadap kemampuan pemecahan masalah siswa di SMP Negeri 1 Rambang.

Data pretest dan posttest dapat dilihat pada tabel 1 berikut.

Tabel 1. Hasil Pretest dan Posttest Kelas Ekperimen dan Kelas Kontrol

\begin{tabular}{lcc}
\hline Kelas & $\begin{array}{c}\text { Rata-rata } \\
\text { Pretest }\end{array}$ & $\begin{array}{c}\text { Rata-rata } \\
\text { Posttest }\end{array}$ \\
\hline Eksperimen & 43,03 & 70,30 \\
Kontrol & 39,76 & 62,07 \\
\hline
\end{tabular}

Berdasarkan hasil penelitian didapat ratarata pretest kelas eksperimen yaitu 43,03 dan kelas kontrol 39,76 . Sedangkan rata-rata posttest mengalami kenaikan pada kelas eksperimen yaitu 70,30 dan kelas kontrol 62,07. Hal ini dapat disimpulkan bahwa peningkatan nilai posttest pada kelas eksperimen lebih tinggi dibanding kelas kontrol.

Penelitian ini dilakukan pada dua kelas sampel yang dipilih dengan menggunakan teknik klaster random, sehingga diperoleh kelas VIII.3 sebagai kelas eksperimen dan kelas VIII.4 sebagai kelas kontrol. Dalam penelitian ini menggunakan desain pretest-posttest control group design. Dalam penelitian ini kelas eksperimen diberikan perlakuan menggunakan pendekatan contextual teaching and learning (CTL) menggunakan laboratorium, sedangkan pada kelas kontrol menggunakan pendekatan diskusi.

Pembelajaran dengan pendekatan CTL menggunakan laboratorium merupakan pembelajaran yang mengaitkan setiap materi atau topik pembelajaran dengan kehidupan nyata, serta diperkuat dengan kegiatan laboratorium yang menghubungkan antara teori/konsep dengan praktek membuat pemahaman mendalam dan bermakna, sehingga kemampuan pemecahan masalah siswa dapat terlatih. Pada pembelajaran CTL menggunakan laboratorium siswa tidak hanya melakukan percobaan untuk menjawab masalah yang diberikan oleh peneliti, tetapi juga dapat menemukan sendiri konsep dari apa yang dipelajari serta dapat membuat hubungannya dengan dunia nyata.

Pada hasil pretest ada beberapa indikator kemampuan pemecahan masalah yang belum muncul atau siswa belum mampu menjawab soal dengan sempurna. Namun pada saat posttest hampir seluruh siswa mampu menyelesaikan atau menjawab soal sesuai dengan indikator kemampuan pemecahan masalah. Persentase data pretest dan posttest untuk tiap indikator kemampuan pemecahan masalah pada kelas eksperimen dapat dilihat pada gambar 2 berikut. 


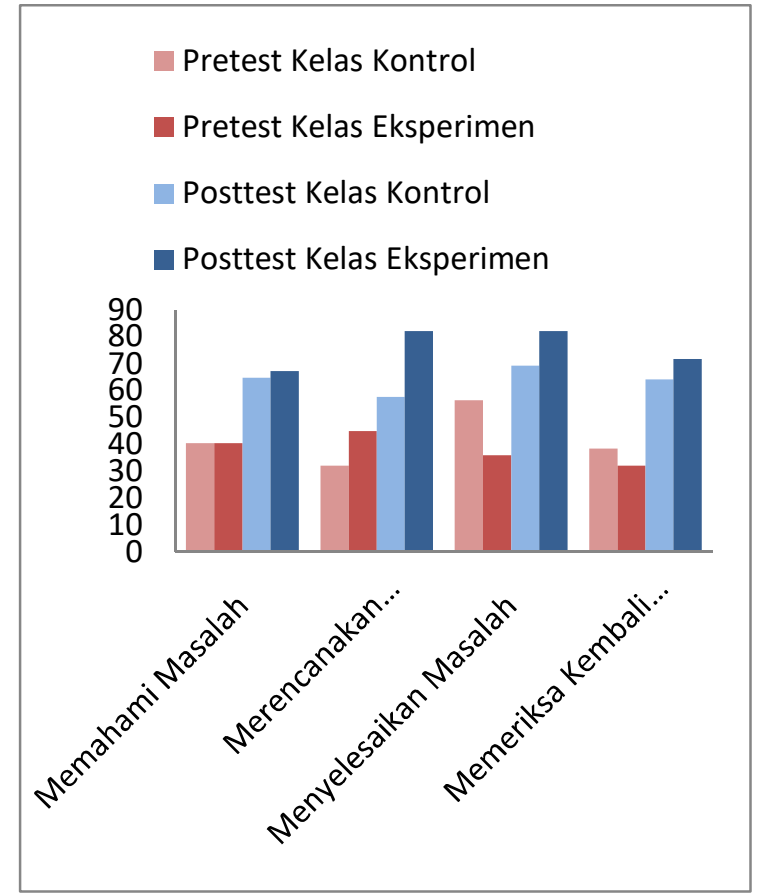

Gambar 2. Grafik Persentase Indikator Kemampuan Pemecahan Masalah Kelas Eksperimen

Berdasarkan diagram di atas menunjukan bahwa skor rata-rata posttest kelas eksperimen mengalami peningkatan setelah dilakukan kegiatan pembelajaran menggunakan pendekatan CTL menggunakan laboratorium. Untuk lebih jelasnya dapat dilihat pada rincian masing-masing indikator dibawah ini:

1. Pada indikator memahami masalah, di kelas eksperimen menunjukkan bahwa persentase siswa memahami masalah pada saat pretest yaitu 40,38\%, dan pada saat posttest yaitu 67,30\%. Hal ini menunjukkan bahwa adanya perubahan atau peningkatan kemampuan pemecahan masalah siswa pada indikator memahami masalah.
2. Pada indikator merencanakan penyelesaian masalah, di kelas eksperimen menunjukkan bahwa persentase siswa merencanakan penyelesaian masalah pada saat pretest yaitu $32,05 \%$, dan pada saat posttest yaitu $82,05 \%$. Hal ini menunjukkan bahwa adanya perubahan atau peningkatan kemampuan pemecahan masalah siswa pada indikator merencanakan penyelesaian masalah karena setelah melakukan pembelajaran siswa sudah dapat menentukan konsep yang akan digunakan untuk menyelesaikan masalah.

3. Pada indikator menyelesaikan masalah, di kelas eksperimen menunjukkan bahwa persentase siswa dapat menyelesaikan masalah pada saat pretest yaitu $56,41 \%$, dan pada saat posttest yaitu 82,05\%. Hal ini menunjukkan bahwa adanya perubahan atau peningkatan kemampuan pemecahan masalah siswa pada indikator menyelesaikan masalah. Hal ini menunjukan bahwa pada saat posttest siswa sudah dapat menuliskan penyelesaian masalah berdasarkan konsep yang telah dipelajari.

4. Pada indikator memeriksa kembali jawaban, di kelas eksperimen menunjukkan bahwa persentase siswa memeriksa kembali jawaban pada saat pretest yaitu $38,46 \%$, dan pada saat posttest yaitu $71,79 \%$. Hal ini menunjukkan bahwa adanya perubahan atau peningkatan kemampuan pemecahan masalah siswa pada indikator memerikasa kembali jawaban. Hal ini menunjukan bahwa pada saat posttest siswa sudah menuliskan kesimpulan berdasarkan masalah. 
Berdasarkan pembahasan hasil tes mengenai kemampuan pemecahan masalah tiap indikator menunjukan bahwa semua indikator kemampuan pemecahan masalah mengalami peningkatan setelah diterapkan pendekatan CTL menggunakan laboratorium. Meningkatnya kemampuan pemecahan masalah karena pada saat belajar siswa terlibat dalam kegiatan yang menuntut mereka untuk mengkonstruksi dan memahami materi yang dipelajari serta dengan berdiskusi mereka dapat berkomunikasi secara aktif sehingga memberikan penguatan pada pemahaman siswa. Hal ini sejalan dengan pendapat Cochran et al (dalam Sari et al, 2014, hal. 58) yang menyatakan bahwa keuntungan pembelajaran dengan pendekatan contextual teaching and learning (CTL) bagi siswa dapat memperdalam pemahaman dan meningkatkan pemecahan masalah.

Meningkatnya indikator kemampuan pemecahan masalah memahami masalah, merencanakan penyelesaian masalah dan menyelesaikan masalah sejalan dengan pendapat yang lainnya yaitu Adiaty et al (2014) yang menyatakan bahwa pembelajaran laboratorium berbantukan kit fisika dengan pendekatan contextual teaching and learning (CTL) dapat memungkinkan siswa untuk menggali, bereksperimen sehingga dapat menemukan dan menemukan sendiri konsep yang dipelajari. Sehingga siswa dapat menangkap hubungan antara pengalaman belajar di sekolah dengan kehidupan nyata sehingga konsep yang dipelajari akan tertanam erat di memori siswa. Pendekatan pembelajaran CTL menganut aliran konstruktivisme dimana siswa dituntut untuk menemukan pengetahuannya sendiri. Dengan menggunakan pengetahuan yang ada memungkinkan siswa untuk dapat memahami masalah, merencanakan penyelesaian masalah, dan menyelesaikan masalah berdasarkan pengalaman belajar maupun dalam kehidupan sehari-hari. Selain itu juga sejalan dengan kelebihan pendekatan CTL menurut Ernayeti (2018) bahwa siswa aktif, kritis, dan kreatif, yang berarti bahwa siswa dapat mengembangkan ide yang ada berdasarkan pengalaman belajarnya.

Pada saat pembelajaran berlangsung siswa terlihat antusias pada saat mengerjakan LKS karena diselesaikan bersama-sama dengan teman sekelompoknya, serta pada saat melakukan percobaan siswa seperti bermain sambil belajar karena percobaan dilakukan dengan menggunakan benda-benda yang ada disekitar siswa. Hal ini sejalan dengan pendapat Johnson (dalam Antika et al, 2016, hal. 231) yang menyatakan bahwa CTL adalah salah satu pendekatan yang lebih banyak melibatkan siswa secara aktif serta menjadikan kegiatan belajar mengajar mengasyikan dengan komponenkomponen yang saling terhubung dan bertujuan menolong para siswa melihat makna yang ada pada setiap pembelajaran yang mereka dapatkan.

Pengambilan kesimpulan dari data yang ada perlu dilakukan uji statistik. Sebelum melakukan uji statistik dilakukan uji prasyarat yaitu uji normalitas dan homogenitas. Data hasil uji normalitan dan homogenitas dapat dilihat pada tabel 2 dan 3.

Tabel 2. Data Hasil Uji Normalitas

\begin{tabular}{ccccc}
\hline Kelas & $X_{h}{ }^{2}$ & $D K$ & $X_{t}^{2}$ & Kesimpulan \\
\hline Eksperimen & 10,56 & 5 & 11,070 & $X_{h}{ }^{2} \leq X_{t}^{2}$
\end{tabular}


Kontrol $6,18 \quad 5 \quad 11,070 \quad X_{h}^{2} \leq X_{t}^{2}$

Tabel 3. Data Hasil Uji Homogenitas

\begin{tabular}{cccc}
\hline Tes & $\mathrm{F}_{\text {hitung }}$ & $\mathrm{F}_{\text {tabel }}$ & Kesimpulan \\
\hline Posttest & 1,59 & 1,98 & $\mathrm{~F}_{\text {hitung }}<\mathrm{F}_{\text {tabel }}$
\end{tabular}

Setelah melakukan uji normalitas dan homogenitas diperoleh data pada masing-masing kelas sampel terdistribusi normal dan memiliki varians data yang homogen.

Hipotesis penelitian diuji dengan menggunakan uji t pihak kanan. Dalam penelitian ini, untuk menguji hipotesis maka hipotesis penelitian diubah menjadi hipotesis statistik yang terdiri dari Ho dan Ha sebagai berikut:

Ho: Tidak ada pengaruh pendekatan contextual teaching learning (CTL) terhadap kemampuan pemecahan masalah siswa di SMP Negeri 1 Rambang.

Ha: Ada pengaruh pendekatan contextual teaching learning (CTL) terhadap kemampuan pemecahan masalah siswa di SMP Negeri 1 Rambang.

Dengan kriteria pengujian tolak Ho jika $t_{\text {hitung }}$ $\geq t_{\text {tabel }}$ dan terima Ho jika $t_{\text {hitung }}<t_{\text {tabel }}$, dengan taraf signifikasi $5 \%$ dan $d k=\left(n_{1}+n_{2}\right)-2$. Data hasil uji hipotesis terdapat pada tabel 4 berikut.

Tabel 4. Data Hasil Uji Hipotesis

\begin{tabular}{ccccc}
\hline Tes & $\mathrm{t}_{\text {hitung }}$ & $\mathrm{Dk}$ & $\mathrm{t}_{\text {tabel }}$ & Keterangan \\
\hline Posttest & 2,51 & 50 & 1,67 & $\mathrm{t}_{\text {hitung }}>\mathrm{t}_{\text {tabel }}$ \\
\hline
\end{tabular}

Berdasarkan perhitungan didapat $t_{\text {hitung }} 2,51$ dan $t_{\text {tabel }} 1,67$ atau $t_{\text {hitung }}>t_{\text {tabel. }}$. Hal ini berarti Ho ditolak, sehingga dapat disimpulkan bahwa ada pengaruh pendekatan contextual teaching and learning (CTL) menggunakan laboratorium terhadap kemampuan pemecahan masalah siswa di SMP Negeri 1 Rambang.

Hasil penelitian ini juga didukung dengan penelitian sebelumnya telah dilakukan oleh Sari et al (2014) tentang implementasi pendekatan contextual teaching and learning (CTL) bernuansa pendidikan karakter untuk meningkatkan kemampuan pemecahan masalah matematis siswa MTsN menunjukkan bahwa peningkatan kemampuan pemahaman matematis siswa yang belajar dengan menggunakan pendekatan contextual teaching and learning secara signifikan lebih baik daripada siswa yang memperoleh pembelajaran dengan pendekatan konvensional secara keseluruhan. Penelitian lainnya yang dilakukan oleh Adiaty et al (2014) bahwa Pembelajaran berbasis laboratorium berbantuan kit fisika dengan pendekatan contextual teaching and learning (CTL) memberikan pengaruh terhadap peningkatan hasil belajar fisika siswa pada tiga ranah penilaian yaitu psikomotor, afektif dan kognitif.

Penelitian lainnya yang dilakukan oleh Dewi Antika dan Alimulfi Arief (2016) dengan hasil penelitian yaitu terdapat peningkatan hasil belajar setelah diterapkan pembelajaran berbasis laboratorium menggunakan pendekatan contextual teaching and learning (CTL) di kelas eksperimen maupun replikasi. Serta penelitian lainnya yang dilakukan oleh Sari et al (2017) dengan hasil penelitian yaitu terdapat perbedaan kemampuan penalaran matematis siswa antara mendapat pendekatan pembelajaran CTL dan yang mendapat pembelajaran konvensional, serta 
kemampuan penalaran matematis siswa yang mendapat pendekatan pembelajaran CTL lebih baik dari yang mendapatkan pembelajaran konvensional.

Adapun kendala yang di alami oleh peneliti selama melakukan penelitian diantaranya yaitu pada saat melakukan pembagian kelompok, siswa susah diatur sehingga kondisi kelas susah di kontrol. Kendala yang ditemui selanjutnya kurangnya waktu yang digunakan pada proses kegiatan pembelajaran, dan keadaan siswa yang kurang bersemangat dalam belajar sehingga siswa tampak malas malas, ini disebabkan karena motivasi belajar siswa kurang dan dapat mempengaruhi saat penelitian. Serta pemakaian ruang laboratorium sebaiknya di jadwalkan terlebih dahulu dengan guru mata pelajaran yang lain, agar ruang laboratorium tidak digunakan secara bersamaan.

\section{KESIMPULAN DAN SARAN}

Berdasarkan hasil penelitian ini dapat disimpulkan bahwa ada pengaruh pendekatan contextual teaching and learning (CTL) menggunakan laboratorium terhadap kemampuan pemecahan masalah siswa di SMP Negeri 1 Rambang. Hal ini dibuktikan dari hasil evaluasi nilai posttest diperoleh nilai $t_{\text {hitung }}(2,51)$ lebih besar dari nilai $t_{\text {tabel }}(1,67)$.

Berdasarkan penelitian yang telah dilakukan peneliti memberikan saran untuk peneliti yang akan datang agar sebelum melakukan penelitian akan lebih baik terlebih dahulu menyusun jadwal pemakaian laboratorium dengan guru yang lain.
Adiaty, F., Masril, \& Hadayati. (2014). Pengaruh Pembelajaran Berbasis Laboratorium Berbantukan Kit Fisika dengan Pendekatan Contextual Teaching and Learning Terhadap Hasil Belajar Fisika Siswa Kelas XI SMAN 8 Padang. Pillar of Physics Education. vol. 2, 81-88.

Antika, D., \& Arief, A. (2016). Penerapan Pembelajaran Berbasis Laboratorium Menggunakan Pendekatan Contextual Teaching and Learning (CTL) untuk Meningkatkan Hasil Belajar Siswa SMA Muhammadiyah 1 Gresik. Jurnal Inovasi Pendidikan Fisika (JIPF), ISSN 2302-4496, 5(3), 230-236.

Ernayeti. (2018). Penerapan Model Pembelajaran Contextual Teacing and Learning untuk Meningkatkan Hasil Belajar IPS Terpadu Siswa Kelas VIII SMP Negeri 2 Inuman. Jurnal PAJAR (Pendidikan dan Pengajaran) Prodi PGSD FKIP Universitas Riau, PISSN 2580-8435, EISSN 2614-1337, 1(1), 129135.

Hafizah, E., Hidayat, A., \& Muhardjito. (2014). Pengaruh Model Pembelajaran Anchored Instruction Terhadap Penguasaan Konsep dan Kemampuan Pemecahan Masalah Fisika Siswa Kelas X. Jurnal Fisika Indonesia, ISSN 1410-2994, vol. 18, 8-12.

Limbong, P. F. (2014). Pengelolaan Laboratorium sekolah (Kasus Laboratorium SMA Unggul Del Tapanuli Utara). Jurnal Pendidikan dan Kepengawasan, ISSN 2442-9422, 2(2), 5054.

Nurcahyo, A. W., Wartono, \& Yuliati, L. (2017). Kemampuan Pemecahan Masalah Hukum Gerak Newon Mahasiswa Melalui Pembelajaran Cooperative Problem Solving. Jurnal Pendidikan, EISSN 2502-471X, 2(7), 963-970.

Prihartanti, D., Yuliati, L., \& Wisodo, H. (2017). Kemampuan Pemecahan Masalah Siswa pada Konsep Impuls, Momentum, dan Teorema Impuls Momentum. Jurnal Pendidikan, EISSN 2502-471X, 2(8), 11491159.

\section{DAFTAR PUSTAKA}


Rohmatin, A., \& Budiningarti, H. (2017). Penerapan Model Pembelajaran Guided Inquiry Berbasis Laboratorium untuk Melatihkan Keterampilan Proses Sains pada Materi Alat-alat Optik Kelas X MIA di SMA Negeri 2 Lamongan. Jurnal Inovasi Pendidikan Fisika (JIPF), ISSN 2302-4496, (3), 209-213.

Sabroni, D. (2017). Pengaruh Model Pembelajaran Contextual Teaching and Learning (CTL) Terdapat Kemampuan Komunikasi Matematis Siswa. Semnas Matematika dan pendidikan Matematika (pp. 55-68). Lampung: UIN Raden Intan Lampung.

Sanjaya, W. (2011). Pemblajaran dalam Implementasi kurikulum Berbasis Kompetensi. Jakarta: Kencana.

Sari, I. P., Yenni, \& Raditya, A. (2017). Pengaruh Pendekatan Pembelajaran Contextual Teaching and Learning (CTL) Terhadap Kemampuan Penalaran Matematis Siswa SMP. Jurnal Pendidikan Matematika, PISSN 2579-9827, EISSN 2580-2216, 1(1), 19-32.

Sari, N. T., Ikhsan, M., \& Hajidin. (2014). Implementasi Pendekatan Contextual Teaching and Learning (CTL) Bernuanssa Pendidikan Karakter untuk Meningkatkan Kemampuan Pemecahan Masalah Matematis Siswa MTsN. Jurnal Didaktik Matematika, ISSN 2355-4185, 2(1), 46-60.

Sugiyono. (2015). Metode Penelitian Pendidikan Pendekatan Kuantitatif, Kualitatif, dan R\&D. Bandung: Alfabeta.

Taqiyyah, S. A., Subali, B., \& Handayani, L. (2017). Implementasi Bahan Ajar Sains Berbahasa Inggris berbasis Metakognitif untuk Meningkatkan Kemampuan Kemampuan Pemecahan Masalah Siswa SMP. Jurnal Inovasi Pendidikan IPA, ISSN 2477-4820, 3(2), 224-234.

Venisari, R., Gunawan, \& Sutrio. (2015). Penerapan Metode Mind Mipping pada Model
Direct Instruction untuk Meningkatkan Kemampuan Pemecahan Masalah Fisika Slswa SMPN 16 Mataram. Jurnal Pendidikan Fisika dan Teknologi, 1(3), 193-198. 